\title{
Crer promovendo o humano: a missão evangelizadora da universidade católica à luz do humanismo cristão
}

Orientador: Abimar Oliveira de Moraes

Doutorando: José Abel de Sousa

Área de Concentração: Teologia Sistemático-Pastoral

Linha de Pesquisa: Fé e Cultura

Projeto de Pesquisa: Questões atuais de Teologia Pastoral

Esta pesquisa busca compreender como a universidade católica pode enfrentar os desafios atuais a fim de interagir com o seu corpo docente e, principalmente, com o discente, a partir dos valores presentes e provenientes do Evangelho de Jesus Cristo. Aborda-se a missão evangelizadora da universidade católica, mais precisamente seu desafio atual na sociedade pluralista. O ponto de partida é o de que o pluralismo cultural e religioso não é apenas externo, encontra-se dentro da própria instituição. $\mathrm{O}$ estudo é realizado a partir do método pastoral tripartido "ver-julgar-agir", inter-relacionado com a Ex Corde Ecclesiae, documento que propõe a definição da identidade e da missão da universidade católica. A universidade católica atual necessita empreender um anúncio da fé cristã que promova o ser humano e que o faça à luz da mensagem do Reino de Deus, que traz consigo os valores cristãos, ainda que nem sempre nomeados como tais. Diante da constatação da existência de um hiato entre a fé e a vida, mostra-se necessário (e possível) que na universidade católica haja uma pastoral universitária ativa e dialogante. Mais que uma universidade em pastoral, que seja uma universidade em pastoralidade, conceito que aponta para um ambiente universitário em que haja atitudes concretas na promoção e defesa da dignidade da pessoa humana, na busca da vivência do humanismo cristão integral e integrado, tendo a solidariedade como eixo norteador. A missão evangelizadora proposta nesta pesquisa visa que a universidade católica adote uma postura de fidelidade aos valores evangélicos e, simultaneamente, valorize e respeite as liberdades, a diversidade religiosa e 
a pluralidade cultural que caracterizam toda a sociedade atual. A ação pastoral realizada no âmbito universitário busca constantemente o diálogo com o mundo contemporâneo conforme anunciado pela Igreja em documentos oficiais: o documento de Buga, a Ex Corde Ecclesiae, o documento conciliar Gravissimum Educationis, o Documento de Aparecida, entre outros. Reitera que o desafio posto à universidade católica atual, considerando que a fidelidade ao múnus da evangelização não é opcional, mas vital, é que faça jus ao adjetivo católica, considerando-se o fato de as referências religiosas nas instituições católicas de ensino universitário encontrarem-se cada vez mais diluídas, sendo absorvidas ou sufocadas pela mentalidade e postura empresarial mercantilista presentes na sociedade da qual a universidade é parte. $O$ adjetivo "católica" equivale a universal, e remete necessariamente aos princípios cristãos como os que iluminam a busca da verdade sobre Deus, o ser humano e a natureza. O título "católica" é o que especifica o dinamismo da universidade, distinguindo-a das outras.

Palavras-chave: Universidade Católica. Dignidade Humana. Fé Cristã. Diálogo e Cultura. Valores Cristãos. 